\title{
PENGARUH KECERDASAN MORAL DAN KESADARAN MORAL TERHADAP PERILAKU BULLIYING SISWA SMA SEDERAJAT DI KABUPATEN LABUHANBATU
}

\author{
Mila Nirmala Sari Hasibuan ${ }^{1}$, Rohana ${ }^{2}$, Siti Zaharah Saragih ${ }^{3}$, Rahma Muti’ah ${ }^{4}$ \\ milanirmalasari7@gmail.com \\ 1, 2, 3, 4 ) STKIP LABUHANBATU
}

\begin{abstract}
Abstrak: Penelitian ini bertujuan untuk mengetahui hubungan antara kecerdasan moral dan kesadaran moral terhadap perilaku bulliying siswa SMA sederajat di kabupaten Labuhanbatu tahun 2019. Penelitian ini menggunakan metode kuantitatif dengan jenis korelasi, adapun populasi dalam penelitian ini berjumlah 46 sekolah dengan jumlah siswa \pm 6.128 siswa, sedangkan sampel dalam penelitian ini menggunakan teknik Random sampling dengan menggunakan rumus slovin, sehingga di peroleh sampel dengan jumlah 364 siswa SMA sederajat. Instrumen dalam penelitian ini terdiri atas angket kecerdasan moral, kesadaran moral, serta perilaku bulliying siswa, berdasarkan olah data tersebut maka di peroleh kesimpulan bahwa kecerdasan moral dan kesadaran moral memiliki hubungan dengan perilaku bulliying.
\end{abstract}

Kata Kunci : Kecerdasan Moral, Kesadaran Moral, Prilaku Bulliying.

\section{PENDAHULUAN}

Salah satu tujuan pendidikan adalah untuk membentuk karakter siswa, dengan harapan dapat mengembangkan dan membentuk watak serta kepribadian siswa dan ini sangat erat kaitannya dengan masalah moral.

Permasalahan moral menjadi masalah utama dalam hidup manusia, penurunan nilai moral pada siswa di tandai dengan adanya perilaku menyimpang seperti tawuran antar siswa, kekerasan, bulliying dan sebagainya. Dan adapun masalah yang akan di teliti adalah kasus yang marak terjadi akhir-akhir ini yaitu kasus perilaku bulliying. Colorosa (dalam Sari Mustika Widya:2017) mengatakan bahwa bulliying merupakan perilaku atau aktivitas yang di lakukan secara sadar, di sengaja dan bertujuan untuk melukai menanamkan ketakutan melalui ancaman agresi lebih lanjut dan menciptakan teror yang didasarkan oleh ketidakseimbangan kekuatan.

$\begin{array}{ccc}\text { Bulliying yang dalam } & \text { bahasa } \\ \text { Indonesianya dapat di artikan sebagai }\end{array}$
penindasan, perundungan, perusakan atau pengintimidasian adalah penggunaan kekerasan, ancaman atau paksaan untuk menyalahgunakan atau mengintimidasi orang lain. Atau menindas dapat juga di artikan sebagai memberlakukan dengan sewenang-wenang, dengan lalim, dengan kekerasan (KKBI, 2003: 486 ).

Penekanan pada tindakan negatif membuat perilaku bulliying berkonotasi dengan tindakan yang di lakukan dengan sengaja atau memberi perasaan tidak nyaman pada orang lain. Seperti mencaci, merendahkan, mencela, memberikan julukan, menendang, mendorong, memukul meminta uang (merampas, memeras) merupakan tindakan nyata dalam bentuk-bentuk bulliying, seperti perilaku yang terkenal di kalangan siswa saat ini adalah memojokkan siswa baru atau adik kelas. Perbuatan tersebut seolah-olah di samakan dengan ungkapan untuk mengajari adek kelas tentang etika di sekolah. 
Perilaku Bulliying bahkan telah di anggap menjadi tradisi sekolahyang di bungkus dengan kalimat "aku dulu sewaktu anak baru juga begitu”. Faturochman (dalam sari permata yuli 2017).

Ada banyak kasus perilaku menyimpang (bulliying) yang di lakukan siswa, ini di perkuat dengan adanya bukti kasus perilaku bulliying yang di lakukan siswa seperti kasus yang viral di tahun 2019 yaitu kasus siswa SMP di keroyok belasan siswa SMA di Pontianak yang memunculkan tagar \# justiceForAudrey, atau ada pula kasus perilaku bulliying siswa terhadap guru seperti yang terjadi di SMP Maha Prajna cilincing Jakarta pada maret 2019, gambaran di atas menunjukkan potret buram dunia pendidikan.

Perilaku bulliying yang di lakukan oleh siswa sebenarnya bermula dari hal - hal kecil yang kemudian membesar, perilaku ini tumbuh dalam diri siswa bisa di akibatkan dari kurangnya pengetahuan ataupun karena ketiadaan atau kurangnya kecerdasan dan kesadaran moral yang termasuk di dalamnya sikap dan kepribadian yang di miliki siswa sehingga tidak memiliki rasa empati. Seperti penelitian yang di lakukan Rahmawati A.R (2013) yang menjelaskan adanya hubungan negatif antara kecerdasan moral dengan perilaku bulliying pada siswa yang berarti semakin tingkat kecerdasan emosional pada siswa maka semakin rendah perilaku bulliying pada siswa dan sebaliknya. Hal ini juga sejalan dengan penelitian yang di lakukan oleh Umasugi (2013 ) tentang adanya hubungan antara regulasi emosi dan religiusitas dengan kecenderungan perilaku bulliying pada remaja, yang menunjukkan adanya hubungan negatif signifikan antara regulasi emosi dan relegiusitas dengan kecenderungan perilaku bulliying.

Kecerdasan dan kesadaran moral memegang peran penting dalam pembentukan perilaku dan karakter peserta didik. Kecerdasan moral (moral intelligence) adalah kemampuan memahami hal yang benar dan yang salah dengan keyakinan etika yang kuat dan bertindak berdasarkan keyakinan tersebut dengan sikap yang benar serta prilaku yang terhormat. Borba (dalam setiawan, 2013 )

Kecerdasan moral akan melahirkan kesadaran moral membuat hidup manusia memiliki tujuan karena tahu apa yang akan di kerjakan dan mengapa di lakukan. Serta hal yang terpenting dari kecerdasan dan kesadaran moral siswa mampu memahami hal yang benar dan salah, di mana dengan adanya kecerdasan dan kesadaran moral tersebut mencakup sifat sifat utama agar anak dalam hal ini siswa bermoral tinggi, sebagai mana yang di kemukakan oleh Borba (dalam Mulyono : 2016 ) kebajikan utama agar anak memiliki moral yang baik yaitu empati , hati nurani, kontrol diri, rasa hormat, kebaikan hati, toleransi dan keadilan. Apabila sifat - sifat tersebut mampu di tanamkan dan tumbuh di hati siswa maka perbuatan perilaku menyimpang dapat di hindari ataupun di hilangkan.

Berdasarkan pemaparan di atas maka penelitian ini akan meneliti apakah ada pengaruh kecerdasan dan kesadaran moral terhadap perilaku bulliying siswa SMA sederajat di kabupaten Labuhanbatu. Penelitian ini dianggap berguna karena hasilnya di harapkan mampu memberi konstribusi dalam dunia pendidikan bagaimana cara mengatasi dan mencegah tindakan bulliying melalui kesadaran dan kecerdasan moral yang di asah di bangku sekolah.

\section{METODE PENELITIAN}

\section{Jenis Penelitian}

Penelitian ini menggunakan metode kuantitatif dengan jenis korelasi,karena dalam penelitian ini membandingkan keberadaan variabel kecerdasan moral dan kesadaran moral terhadap perilaku bulliying siswa pada sampel yang berbeda, dengan hipotesa pertama kecerdasan moral dan hipotesa kedua kesadaran moral, sedangkan hipotesa ketiga perilaku bulliying siswa SMA sederajat di Labuhanbatu. 


\section{Populasi dan Sampel}

Populasi dalam penelitian ini adalah seluruh siswa SMA sederajat di kabupaten Labuhanbatu yang berjumlah 46 sekolah dengan populasi seluruh siswa kelas X dan XI yang berjumlah \pm 6.128 . Adapun sampel dalam penelitian ini menggunakan teknik random sampling dengan menggunakan rumus slovin sehingga di peroleh sampel penelitian berjumlah 346 siswa.

Variabel Penelitian dan Defensi Operasional Penelitian ini terdiri dari 3 variabel yaitu :

1.Kecerdasan moral ( variabel X1)

2.Kesadaran moral ( variabel X2)

3.Perilaku bulliying siswa ( variabel Y )

Alat Pengumpul Data

Alat yang digunakan dalam pengumpulan data di penelitian ini, menggunakan 3 angket yaitu skala kecerdasan moral, skala kesadaran moral dan skala perilaku bulliying siswa yang di susun sendiri oleh peneliti, di mana menurut Sugiono ( 2016 ) teknik pengumpulan data merupakan langkah yang paling strategis dalam penelitian, karena tujuan utama dari penelitian adalah mendapatkan data, tanpa mengetahui teknik pengumpulan data, maka peneliti tidak akan mendapatkan data yang memenuhi standar data yang di tetapkan.

Dari hasil uji validitas pada angket kecerdasan moral dari 35 item diperoleh 20 item valid dengan nilai korelasi $(0,346 \mathrm{~s} / \mathrm{d}$ 0,888 > 0.34) dan nilai reliabilitas adalah $0.943>0.60$ kemudian angket kesadaran moral dari 40 item diperoleh 36 item valid dengan nilai korelasi (0,381 s/d 0,869>0.34 ) dan nilai reliabilitas adalah $0.931>0.60$ sedangkan untuk angket perilaku bulliying dari 40 item diperoleh 32item valid dengan nilai korelasi ( 0,346 s/d $0,746>0.34)$ dan nilai reabilitas adalah $0,925>$ 0.60

\section{Analisis Data}

Analisis data menggunakan uji Wilcoxon Signed Rank Test, di mana uji nonparametris untuk mengukur signifikansi perbedaan antara dua (2) kelompok data berpasangan berskala ordinal atau interval tetapi berdistribusi tidak normal. Di mana ini di gunakan untuk menganalisis hasil-hasil pengamatan yang berpasangan dari dua data apakah berbeda atau tidak, dalam hal ini kecerdasan dan kesadaran moral terhadap perilaku bulliying siswa.

\section{HASIL PENELITIAN}

Berdasarkan hasil penelitian dengan uji Wilcoxon Signed Ranks Test tentang kecerdasan moral, kesadaran moral dan perilaku bulliying siswa SMA sederajat di kabupaten Labuhanbatu di antaranya adalah :

a) Uji prasyarat

Uji prasyarat analisis yang digunakan adalah uji normalitas. Dibawah ini akan diperlihatkan hasil uji normalitas dari kedua variabel:

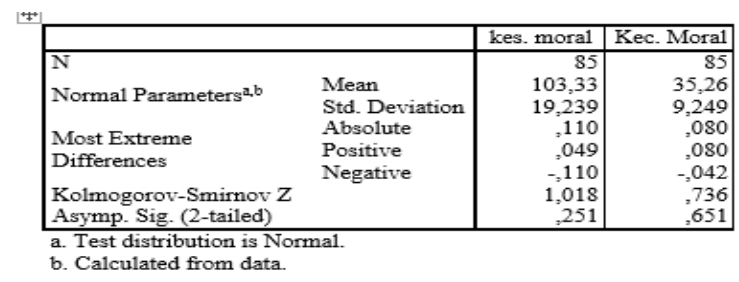

Berdasarkan data diatas diperoleh hasil Asympt.Sig. (2-tailed) yaitu (0.251 dan 0.651) > 0.05, sehingga dapat disimpulkan bahwa data kesadaran moral dan kecerdasan moral tidak terdistribusi normal, sehingga untuk uji hipotesis menggunakan uji non parametrik yaitu Uji Mann-Whitney.

b) Uji Hipotesis

\section{Kesadaran Moral Terhadap Perilaku Bulliying}

\section{Wilcoxon Signed Ranks Test}

\begin{tabular}{|c|c|c|c|c|}
\hline \multicolumn{5}{|l|}{ Ranks } \\
\hline & & N & Mean Rank & Sum of Ranks \\
\hline \multirow{4}{*}{ 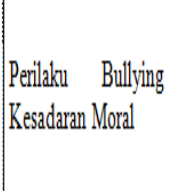 } & Negative Ranks & $344^{\circ}$ & 172,50 & 59340,00 \\
\hline & Positive Ranks & $0^{b}$ & $: 00$ & $: 00$ \\
\hline & Ties & $0^{\circ}$ & & \\
\hline & Total & 344 & & \\
\hline
\end{tabular}

a. Wilcoxon Signed Ranks Test

b. Based on negative ranks. 
Berdasarkan table diatas diperoleh hasil signifikansi Asymp. Sig. (2-tailed) 0,000 < dari 0,05 sehingga dapat disimpulkan bahwa ho: ditolak sehingga ada pengaruh antara kesadaran moral terhadap perilaku bulliying jika dilihat dari nilai $\mathrm{z}$ - 10,668 dengan arah negative sehingga disimpulkan bahwa jika kecerdasan moral tinggi maka perilaku bulliying siswa akan rendah begitu sebaliknya jika kecerdasan moral siswa rendah maka siswa cenderung melakukan perilaku bulliying.

\section{Pembahasan}

Berdasarkan hasil penelitian dapat di lihat bahwa dari dua hipotesa ho ditolak dan ha diterima, sehingga ada pengaruh antara kecerdasan dan kesadaran moral terhadap perilaku bulliying siswa dan hasil penelitian ini berarti dapat mendukung penelitian - penelitian sebelumnya seperti yang di lakukan oleh A.R Rahmawati ( 2013 ) dan Umagi ( 2013 ) yang mengatakan bahwa ada hubungan antara kecerdasan dan kesadaran moral terhadap perilaku bulliying.

\section{KESIMPULAN}

Berdasarkan hasil penelitian , maka diambillah kesimpulan sebagai berikut :

1.Terdapat hubungan perilaku bulliying dengan kecerdasan dan kesadaran moral siswa, dimana jika kecerdasan dan kesadaran moral siswa tinggi maka perilaku bulliying akan rendah.

2.Terdapat hubungan antara kecerdasan dan kesadaran moral dengan perilaku bulliyingartinya semakin tinggi kecerdasan moral siswa maka semakin rendah perilaku bulliying demilkian juga sebaliknya.

\section{SARAN}

1.Kecerdasan dan kesadaran moral siswa harus di tanamkan dan di ajarkan sejak dini mulai dari lingkungan keluarga,masyarakat dan sekolah.

2.Kecerdasan dan kesadaran moral siswa harus lebih di tingkatkan agar perilaku bulliying dapat di hilangkan.
3.Guru sebagai garda terdepan harus mampumendeteksi perilaku bulliying, mencegah, dan lebih mengarahkan siswa pada perilaku baik dan positif.

\section{DAFTAR PUSTAKA}

Djuwita ratna, Bulliying kekerasan terselubung di sekolah,Bumi Aksara, Jakarta, 2008.

T.Andini \& A.Aditya Kamus besar bahasa Indonesia (KKBI ), Prima Media, Surabaya. 2003.

Sugiono,Metode penelitian kuantitatif kualitatif dan R\& D, Alfabeta Bandung, 2012.

A.R Rahmawati , Hubungan anatara kecerdasan emosional dan perilakuBulliying pada siswa siswi kelas XI jurusan administrasi $\begin{array}{llll}\text { perkantoran } & \text { SMK Negeri } 7\end{array}$ Yogyakarta, Skripsi Fakultas ilmu sosial dan humaniora UIN Sunan Kalijaga Yogyakarta, 2013.

D.Setiawan,Peran pendidikan karakter dalam mengembangkan Kecerdasan moral, jurnal pendidikan karakter 56, 2013.

Mulyono Sri Dewi, Model pengembangan kecerdasan moral dalam Menanggulangi perilaku menyimpang siswa, Jurnal Sosioreligi, Vol 14 No 1 Edisi Maret 2016.

Sari Permata Yuli dan Azwar Welhendrifenomena bulliying siswi Studi tentang motif perilaku bulliying siswa SMP Negeri 01Painan, Sumatera Barat, Ijtimaiyah: Jurnal pengembangan Masyarakat Islam 10 (2)(2017) 333 - 367.

Sari mustika widya,Perilaku bulliying di tinjau dari kecerdasan emosional dan konformitas teman sebaya pada remaja, Skripsi, Fakultas ilmu Sosial dan humaiora, UIN Sunan Kalijaga, Yogyakarta, 2017. 
Umasugi S.C, Hubungan antara regulasi emosidan religuisitas dengan kecenderungan bulliying pada remaja, Emphaty, Jurnal fakultas psikologi, Vol 2 No2 Juli, 2013. 